\title{
Vegetative Propagation of Brazilian Native Species for Restoration of Degraded Areas
}

\author{
Paula Wolff Kettenhuber ${ }^{1}$ (D), Rita Sousa ${ }^{1}$ (D), Fabrício Sutili ${ }^{1}$ \\ ${ }^{1}$ Universidade Federal de Santa Maria - UFSM, Santa Maria/RS, Brasil
}

\begin{abstract}
Vegetative propagation by live cuttings is an alternative to reproduce native plants with the potential to be used in restoration of riparian forests and degraded areas. This propagation capacity is intrinsic to each species and is influenced by several factors, particularly the time of the year when cuttings are collected. The aim of this work was to investigate the influence of the season of the year on the vegetative propagation of live cuttings for the species Allamanda cathartica, Cephalanthus glabratus, Escallonia bifida, Ludwigia elegans, Sambucus australis, Sesbania virgata and Terminalia australis. The experiment was conducted at the Soil Bioengineering Laboratory of the Federal University of Santa Maria during two periods of the year (autumn/winter and late winter/spring). All species presented vegetative propagation capacity ranging from $23.3 \%$ to $100 \%$, and the species generally showed better results in late winter/spring.
\end{abstract}

Keywords: ecological restoration, soil bioengineering, live cuttings, biotechnical properties. 


\section{INTRODUCTION}

The Atlantic Forest is one of 25 biodiversity hotspots worldwide (Myers et al., 2000). Territorial occupation and disorganized use of natural resources have reduced its territory to less than $8 \%$ of its original extent, resulting in severe changes to the ecosystems that make up this biome, especially due to the loss and fragmentation of habitats (Tabarelli et al., 2005). The conservation of biodiversity and water resources in this biome can be aided by implementing Soil Bioengineering projects and the Recovery of Degraded Areas that ensure the protection and stability of watercourses and their banks, slopes and other areas with erosive processes.

Vegetative propagation by cuttings is an alternative for the multiplication of native plants with potential use in recovering riparian forests and degraded areas, especially in the case of species with low germinative power (Costa et al., 2013; Nienow et al., 2010; Oliveira et al., 2001). This technique enables obtaining plant material (live cuttings) from mother plants near the intervention site which are more adapted to the local edaphoclimatic conditions, in order to produce a large quantity of seedlings in a shorter period of time and with reduced costs. Additionally, the use of live cuttings contributes to immediate soil stabilization (Abate \& Grotta, 2009; Menegazi \& Palmeri, 2013). Dias et al. (2012) recommend that in using vegetative propagation of native species for environmental purposes, it is essential that the collection be carried out from the greatest number of mother plants possible in order to increase genetic variability among the created individuals.

The capacity of vegetative propagation by cuttings is intrinsic to each species, and it can be influenced by internal factors such as the physiological condition, age, phytosanitary status of the mother plant, its hormonal balance, the existence of anatomical barriers to rooting, the presence of leaves and buds and the time of year, as well as by external factors that refer to the environmental conditions provided during rooting such as water availability, temperature, light and substrate (Owusu et al., 2014; Amri et al., 2010; Dias et al., 2012; Monteiro et al., 2010; Husen \& Pal, 2006; Fachinello et al., 2005; Hartmann et al., 2002).

The season of the year in which the cutting is performed can significantly influence the rooting capacity of some species. The cutting collection period is closely related to the cuttings' consistency and to the physiological conditions, hormonal balance and lignification degree of the mother plant (Fachinello et al., 2005; Hartmann et al., 2002). For species considered as easily-rooted the season of the year does not influence root formation, however, satisfactory rooting rates are only observed for other species when the cuttings occur at specific periods, which generally coincide with the rest period or vegetative growth period (Stuepp et al., 2017, 2015; Rios \& Ribeiro, 2014; Oliveira \& Ribeiro, 2013; Pivetta et al., 2012; Pizzatto et al., 2011; Lima et al., 2011; Bortolini et al., 2008).

The present study aimed to evaluate the seasonal effect on the vegetative propagation capacity and the initial root system and shoot development of the species Allamanda cathartica L., Cephalanthus glabratus (Spreng.) K. Schum., Escallonia bifida Link \& Otto, Ludwigia elegans (Camb.) H. Hara, Sambucus australis Cham. \& Schltdl., Sesbania virgata (Cav.) Pers., and Terminalia australis Camb., popularly known in Brazil as alamanda-amarela, sarandi-branco, canudo-de-pito, cruz-de-malta, sabugueiro, cambaí-amarelo, and sarandi-amarelo, respectively. All these are pioneer species that naturally inhabit riparian zones and have wide geographic distribution throughout the Atlantic Forest Biome.

\section{MATERIAL AND METHODS}

The vegetal material collections for producing the cuttings were carried out in mother plants located in the central region of the state of Rio Grande do Sul, specifically in the municipalities of Santa Maria, Faxinal do Soturno, Silveira Martins, and Júlio de Castilhos. The climate of the region is classified as Cfa 2 according to Köppen's classification, defined as subtropical (Alvares et al., 2013). Annual rainfall levels range from 1,500 to $1,750 \mathrm{~mm}$, with rainfall distributed throughout the year; however, periods of water deficit may occur in the summer months. The municipality of Santa Maria presents average annual temperature of $19^{\circ} \mathrm{C}$, with an average temperature of around $24.8^{\circ} \mathrm{C}$ in the warmest month, and around $14.1^{\circ} \mathrm{C}$ in the coldest month (Moreno, 1961).

Mother plants that appeared to have good phytosanitary conditions, age and similar morphological characteristics 
were selected. Branches were preferably collected from the last vegetative cycle as a whole, packed into plastic bags and then transported to the Soil Bioengineering Laboratory of the Federal University of Santa Maria. The cuttings were made from the central part of the branch without leaves using a straight cut, with a length of $20 \mathrm{~cm}$ and diameter ranging from 5 to $15 \mathrm{~mm}$, keeping at least two buds in each cutting. The cuttings were planted in the proportion 2/3 buried in 1.7-liter pots filled with medium-sifted sand. The experiment was conducted in an automated greenhouse at a temperature between $20^{\circ} \mathrm{C}$ and $30^{\circ} \mathrm{C}$ using drip irrigation of $10 \mathrm{ml}$ three times a day (09:00, 13:00 and 17:00).

The vegetative propagation capacity and development of the shoot and root system of the species were evaluated at two different times/seasons of the year: autumn/winter (April 2, 2016 to July 2, 2016) and late winter/spring (September 6, 2016 to December 6, 2016).

The experimental design was completely randomized with 60 repetitions (cuttings) for each species at each season of the year (autumn/winter and late winter/spring), totaling 120 cuttings per species.

The survival rate, rooting percentage, shoot (dry mass of the primary shoot per plant) and root system variables (average number of roots and sum of root length and root dry mass per plant) were evaluated after 90 days. It was also possible to calculate the number of roots per meter of buried cuttings based on the values of the average number of primary roots in order to better compare with studies that used different cuttings sizes. Primary shoots and roots were considered as those directly attached to the cutting.

Statistical analyses were performed using the $\mathrm{R}$ software version 3.3.2. (R Development Core Team) and Excel (2013). The homogeneity of variances was verified by the Bartlett test and the means of the variables were compared by the non-parametric Mann-Whitney test at $5 \%$ probability level $(\mathrm{p}<0.05)$.

\section{RESULTS AND DISCUSSION}

The highest values of survival and rooting were observed for L. elegans in the two evaluated seasons of the year (98.3\% and 100\%), while C. glabratus had a survival rate of $96.7 \%$ and rooting of $86.7 \%$ in the late winter/spring, A. cathartica had a survival rate of $93.3 \%$ and rooting of $81.7 \%$ in the late winter/spring, and S. virgata had survival and rooting rates of $91.7 \%$ in the autumn/winter (Figure 1).

According to Schiechtl (1973) and Cornelini \& Ferrari (2008), plants should present survival rates $\geq 70 \%$

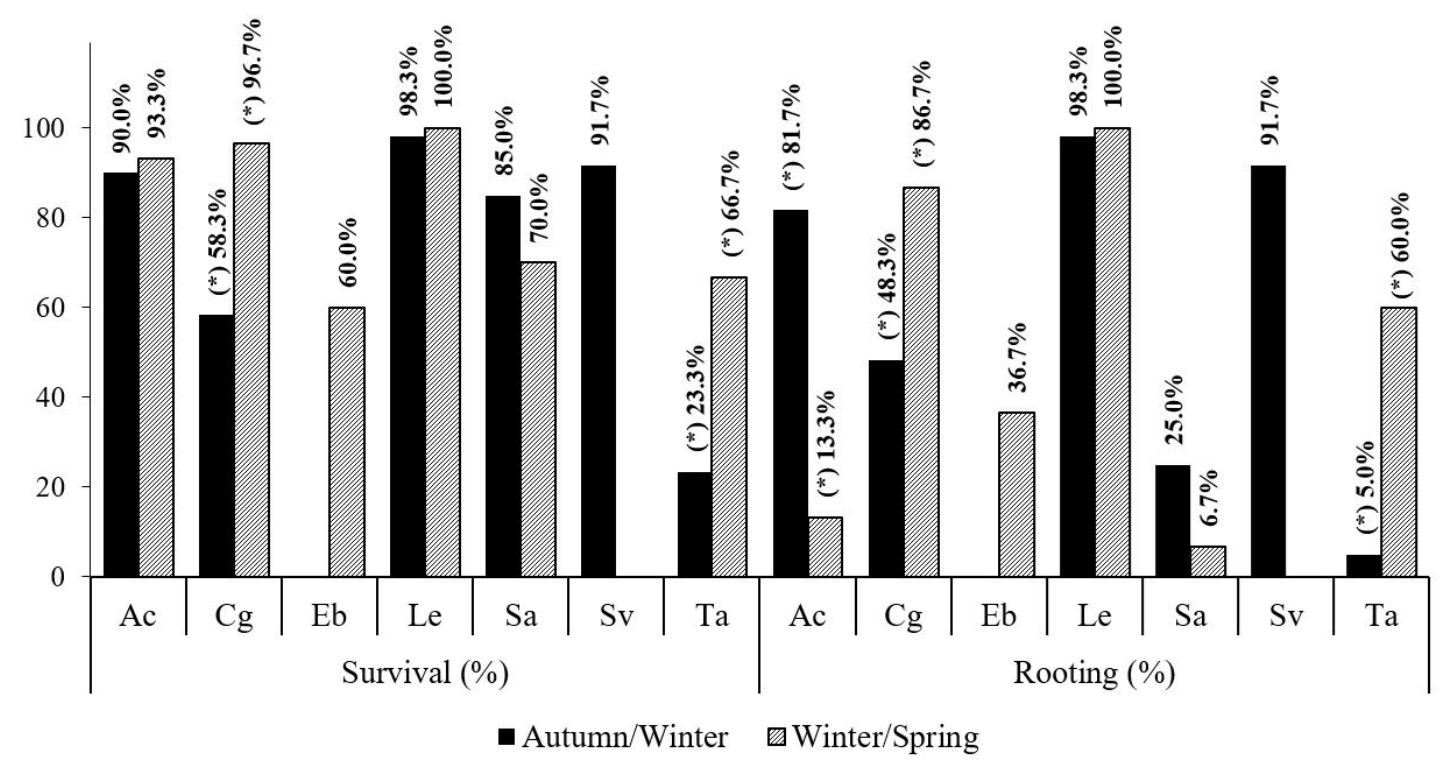

Figure 1. Survival and rooting rates of the studied species obtained in two periods of assessment after 90 days of planting. Ac = Allamanda cathartica $\mathrm{Cg}=$ Cephalanthus glabratus; Eb = Escallonia bifida $; \mathrm{Le}=$ Ludwigia elegans; $\mathrm{Sa}=$ Sambucus australis; $\mathrm{Sv}=$ Sesbania virgata; $\mathrm{Ta}=$ Terminalia australis. ${ }^{\star}$ ) significance level of $5 \%$ probability by Mann-Whitney test. 
in order to be used as cuttings in Soil Bioengineering interventions. With the exception of E. bifida, all other species obtained survival rates close to or greater than this value.

A significant difference $(\mathrm{p}<0.05)$ was found for the survival rate between the seasons of the year for C. glabratus and T. australis. These species had significantly higher survival rates in the late winter/spring period, with increases in the survival rate of $38.4 \%$ and $43.4 \%$, respectively.

No significant differences were found in the survival rate between the evaluated periods for the species L. elegans, A. cathartica and S. australis ( $\mathrm{p}>0.05$ ), which was also observed for the rooting percentage of L. elegans and S. australis. Whereas the percentage of rooting differed significantly for A. cathartica, presenting a high variation between autumn/winter (81.7\%) and the late winter/spring (13.3\%).

The low percentage of rooting in A. cathartica in the late winter/spring is probably due to the fact that the mother plants of this species were flowering at the time the cutting was carried out. Santos et al. (2011) and Bortolini et al. (2008) also attributed the lower rooting percentages of Cestrum laevigatum and Tibouchina sellowiana to the influence of flowering of the mother plants at the collection time. For Hartmann et al. (2002) and Oliveira et al. (2001), when plants are in the flowering/fruiting period, the metabolites are directed to producing flowers and fruits, and the assimilates required for rooting are in lower concentrations.

It was not possible to carry out statistical analysis for the E. bifida and S. virgata species. No live cuttings for the E. bifida species were observed at the time of evaluation in the autumn/winter period due to all the cuttings rotting, possibly resulting from the lower tolerance of this species to excess moisture within the greenhouse during this period. According to Xavier \& Santos (2002), excess water can hinder gas exchanges, thereby favoring development of diseases which make rooting difficult and lead to the death of plant tissues. The survival rate of E. bifida was $60 \%$ in the late winter/spring period and the rooting rate was only $36.7 \%$.

Meanwhile, no evaluations for the $S$. virgata species were carried out in the late winter/spring period, since there was a high mortality of cuttings in this period caused by an attack of larvae that fed on the inside of the cuttings forming galleries. Sánchez-Soto et al. (2003) reported the occurrence of the insect Neodiplogrammus quadrivittatus (Olivier) in S. virgata plants in the state of São Paulo. The occurrence of this insect has also been reported in Sesbania punicea and Cassia corymbosa plants in Rio Grande do Sul state (Silva et al., 1968). According to the authors, the insect's larva feeds inside the stem and branches of the host plant, making longitudinal galleries towards the root, which cause depletion and death of the branch or of the plant.

The $S$. australis species presented survival rates considered good to excellent and intense sprouting, however, the rooting percentage was low in both periods of the year (25\% and $6.7 \%)$. The difficulty in rooting for this species may be associated with the presence of anatomical barriers or the hormonal balance of the species. Gratieri-Sossella et al. (2008) observed similar behavior in cuttings of the Erythrina crista-galli species and attributed this fact to the intense budding of the cuttings, possibly consuming more nutritional reserves to the detriment of root formation. According to Hartmann et al. (2002), low auxin levels and high levels of cytokinin tend to favor shoot formation rather than root formation. For the same authors, high concentrations of gibberellins and the absence of rooting co-factors may also hinder root production.

Plants used in projects of Soil Bioengineering and Recovery of Degraded Areas not only need to be able to survive adverse conditions, but also to solve the existing technical problem, which is achieved through rapid development and good production of roots and shoots (Durlo et al., 2010).

The dry mass of the shoots in the two seasons differed significantly among all studied species (Table 1). Shoot dry mass was considerably higher in the late winter/spring period for the C. glabratus, $L$ elegans, and T. australis species, with increases of $1.455 \mathrm{~g}, 1.624 \mathrm{~g}$ and $0.669 \mathrm{~g}$, respectively. In contrast, the A. cathartica and S. australis species showed higher shoot development in the autumn/winter period.

The use of species that produce higher shoot volume is indicated for Soil Bioengineering projects. This characteristic is especially important for the control of surface erosion and soil protection (Coppin \& Richards, 2007).

However, Durlo \& Sutili (2014) emphasize that although it is important to obtain information related 
Table 1. Results of the shoots and root system variables.

\begin{tabular}{|c|c|c|c|c|c|c|c|c|c|c|c|c|}
\hline \multirow{2}{*}{ Species } & \multicolumn{2}{|c|}{ NR } & \multirow{2}{*}{ p-value } & \multicolumn{2}{|c|}{$\operatorname{RLS}(\mathrm{cm})$} & \multirow{2}{*}{ p-value } & \multicolumn{2}{|c|}{ RDM (g) } & \multirow{2}{*}{ p-value } & \multicolumn{2}{|c|}{ SDM (g) } & \multirow{2}{*}{ p-value } \\
\hline & P1 & P2 & & P1 & P2 & & P1 & P2 & & P1 & P2 & \\
\hline Ac & 11 & 7.5 & 0.161 & 49 & 30.05 & 0.191 & 0.233 & 0.03 & $0.019^{*}$ & 0.474 & 0.163 & $0.024^{*}$ \\
\hline $\mathrm{Cg}$ & 4 & 19 & $0.000^{*}$ & 31 & 163.4 & $0.000^{*}$ & 0.082 & 0.464 & $0.000^{*}$ & 0.164 & 1.619 & $0.000^{*}$ \\
\hline $\mathbf{E b}$ & 0 & 3 & - & 0.0 & 10.1 & - & 0.0 & 0.01 & - & 0.0 & 0.409 & - \\
\hline Le & 32 & 90 & $0.000^{*}$ & 255.9 & 666.4 & $0.000^{*}$ & 0.271 & 0.868 & $0.000^{*}$ & 0.43 & 2.054 & $0.000^{*}$ \\
\hline Sa & 1 & 1.5 & 1.000 & 5.3 & 3.45 & 0.940 & 0.017 & 0.003 & 0.151 & 0.398 & 0.23 & $0.002^{*}$ \\
\hline Sv & 28 & - & - & 255.4 & - & - & 0.221 & - & - & 0.278 & - & - \\
\hline $\mathrm{Ta}$ & 1 & 4 & $0.024^{*}$ & 20.4 & 32.8 & 0.3068 & 0.073 & 0.838 & $0.000^{*}$ & 0.033 & 0.702 & $0.000^{*}$ \\
\hline
\end{tabular}

Average number of roots (NR), roots length sum (RLS), root dry mass (RDM), and shoot dry mass (SDM) per plant in the two assessment periods after 90 days of planting. P1 = Experiment installed in the autumn/winter period; P2 = Experiment installed during the late winter/spring. $\mathrm{Ac}=$ Allamanda cathartica $; \mathrm{Cg}=$ Cephalanthus glabratus; $\mathrm{Eb}=$ Escallonia bifida $; \mathrm{Le}=$ Ludwigia elegans; $\mathrm{Sa}=$ Sambucus australis; $\mathrm{Sv}=$ Sesbania virgata $; \mathrm{Ta}=$ Terminalia australis; ${ }^{*}$ Significant at a $5 \%$ probability level by the Mann-Whitney test.

to the shoot, the main characteristics to be evaluated for use in Soil Bioengineering interventions are related to the plant's root system. Species with well-developed root systems improve soil water infiltration and drainage, structuring and confining soil layers, and increase its shear strength (Sousa \& Sutili, 2017).

The season effect did not influence the root production of A. cathartica and S. australis, which presented the same number of roots on average between the two periods (Table 1).

The amount of primary roots produced by L. elegans, C. glabratus, and T. australis was significantly higher in the late winter/spring. These results corroborate studies by Nicoloso et al. (1999) and Pizzatto et al. (2011), who found higher primary root production in spring when compared to autumn and winter in studying the vegetative propagation of Platanus acerifolia and Hibiscus rosa-sinensis at different seasons/periods of the year. For these authors, the production of primary roots in live cuttings may be linked to the endogenous content of indoleacetic acid (IAA) and to the temperature during the experiment. According to Taiz \& Zeiger (2013), the highest IAA synthesis rate (the main auxin in plants) occurs at shoot growth points (buds and young leaves), in which the production of this phytohormone is higher in the spring, thus justifying the tendency of a greater number of roots observed in the collected cuttings during this period. According to the same authors, temperature has a direct effect on plant metabolism, and the higher the temperature, the more accelerated the chemical reactions will be, which may have favored the better root development during the spring. According to Nicoloso et al. (1999), the low root production in autumn is possibly associated with lower temperatures and a high content of inhibitors, common in the dormancy phase.

The same conditions that possibly influenced the higher production of primary roots in the late winter/spring probably also influenced the sum of their length, which was considerably higher in this period for L. elegans and C. glabratus. No significant differences were observed for this parameter for the other species. Ono et al. (1994) also observed significantly higher primary root development in spring compared to autumn in Platanus acerifolia cuttings.

The analysis of root distribution by length class of the species that showed the greatest root system development after 90 days of planting showed that $80 \%$ of the roots of A. cathartica were between 0.6 and $10 \mathrm{~cm}$, and the largest roots were about $20 \mathrm{~cm}$. A similar distribution was observed for the L. elegans species, in which $78 \%$ of the roots were between 0.4 and $10 \mathrm{~cm}$, and $70 \%$ of the total roots for S. virgata were between 0.5 and $10 \mathrm{~cm}$, the longest roots of these species were approximately 50 and $60 \mathrm{~cm}$, respectively. On the other hand, the C. glabratus species had most of its roots (43\%) between 5 and $10 \mathrm{~cm}$, with the longest roots reaching about $35 \mathrm{~cm}$. Such information is relevant for the use of these species in interventions that aim at controlling surface erosion and soil stabilization, since fine roots that concentrate in the first layers of soil help in structuring and reducing soil loss, and longer roots act as rods helping to structure the soil layers by anchoring, arching and shoring the soil (Sousa \& Sutili, 2017).

Root dry mass was the variable related to the root system showing the greatest variation among 
the evaluated periods of the year, being significant for the species A. cathartica, C. glabratus, L. elegans, and T. australis. In comparing the two periods of the year, the root dry mass was generally higher during the late winter/spring. This result is in agreement with Borges \& Martins-Corder (2002), who compared two experiments with Acacia mearnsii, one of them carried out in the autumn and another in the spring, and found a $35 \%$ increase in the average dry weight of roots in the spring.

An exception was observed for $A$. cathartica, which presented a higher root dry mass in the autumn/winter, possibly due to the fact that the mother plants were flowering during the collection period at the end of winter/spring, as previously explained.

Unlike the others, the root dry mass of S. australis did not differ significantly between the periods of the year, with observed values practically null.

By analyzing the number of primary roots per meter of buried cuttings, the high root production in L. elegans is even more evident, reaching 448 roots $/ \mathrm{m}$ in the late winter/spring and 182 roots $/ \mathrm{m}$ in the autumn/winter 90 days after planting (Figure 2). These values exceed those observed by Sutili et al. (2018) for Phyllanthus sellowianus with 130 roots/m and Salix $X$ rubens with 144 roots/m in the spring/summer

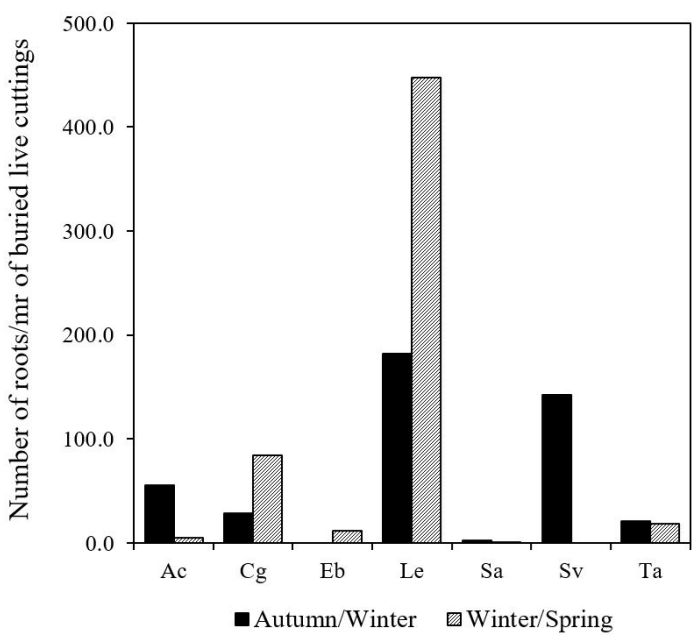

Figure 2. Number of roots per meter of buried live cuttings of the studied species obtained in two periods of assessment 90 days after planting. $\mathrm{Ac}=$ Allamanda cathartica; $\mathrm{Cg}=$ Cephalanthus glabratus; $\mathrm{Eb}=$ Escallonia bifida; Le = Ludwigia elegans; $\mathrm{Sa}=$ Sambucus australis; $\mathrm{Sv}=$ Sesbania virgata; $\mathrm{Ta}=$ Terminalia australis period, and Salix humboldtiana with 74 roots $/ \mathrm{m}$ and Gymnanthes schottiana with 51 roots/m and $5 \mathrm{~m}$ in the autumn/winter 150 days after planting. The biotechnical potential of these species has already been proven and its use is consolidated in projects of Soil Bioengineering and Recovery of Degraded Areas.

In comparing these results it is possible to state that the species $S$. virgata, C. glabratus, A. cathartica, and T. australis also produced satisfactory values of primary roots with 143 roots $/ \mathrm{m}, 84$ roots $/ \mathrm{m}, 56$ roots $/ \mathrm{m}$, and $21 \mathrm{roots} / \mathrm{m}$, respectively.

Simultaneous analysis of the root system parameters allows for concluding that L. elegans (Figure 3F, G), S. virgata (Figure 3J), C. glabratus (Figure 3C, D), and A. cathartica (Figure 3A, B) are able to produce good to excellent early developmental rhythm in the root system. The use of the T. australis species (Figure 3L, M) should not be rejected because even though it did not present a long root system during the evaluation period, this species was able to produce a good number of roots and possibly needs a longer period for developing its root system.

E. bifida (Figure 3E) and S. australis (Figure 3H, I) did not present satisfactory development for their use in the form of cuttings, however they have morphological and ecological characteristics that qualify them to be used in Soil Bioengineering interventions and Recovery of Degraded Areas, and can be propagated by seeds (Fritsch \& Cervi, 2011; Santander \& González, 2007; Reitz et al., 1988).

In general, the period in this study that presented the highest rates of survival and rooting of the species and greater development of the root and shoot system was the end of winter/spring, coinciding with the end of the dormancy period and beginning of the vegetative growth period. This result corroborates Sutili et al. (2018), who found higher survival rates and greater shoot and root production in Phyllanthus sellowianus and Salix $X$ rubens species cuttings for the same period compared to the autumn/winter. Better rooting rates were also observed in spring for (live) cuttings of Psycotria nuda (Nery et al., 2014), Ficus adathodigifolia (Santos et al., 2011), Hibiscus rosa-sinensis (Pizzatto et al., 2011), and Tibouchina sellowiana (Bortolini et al., 2008).

According to Hartmann et al. (2002), plants in the spring are in the active growth phase, with great hormonal production and nutrient assimilation. 


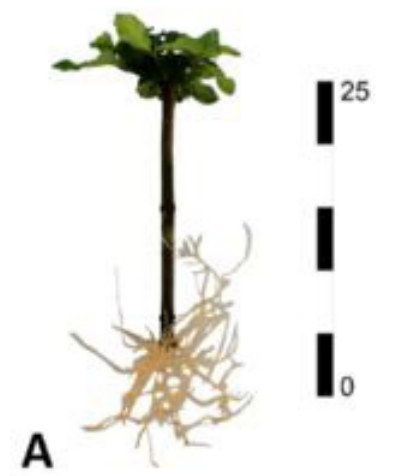

B
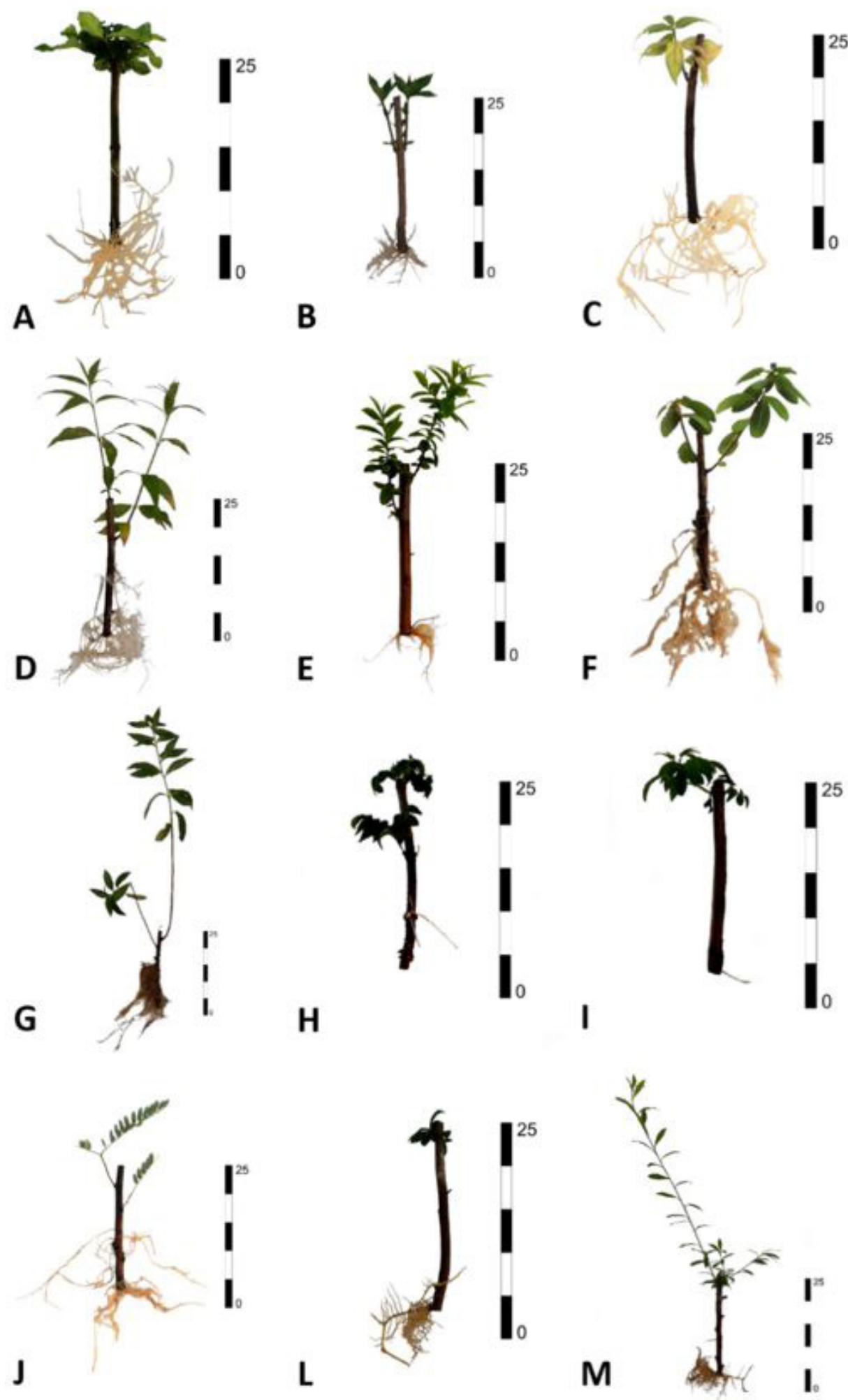

Figure 3. General aspects of the studied species live cuttings in two seasons of the year (fall/winter and late winter/spring) 90 days after planting, with the exception of the specie E. bifida, which only presented survival data in the late winter/spring period, and S. virgata, which was only evaluated in the fall/winter period. (A and B) A. cathartica; (C and D) C. glabratus; (E) E. bifida; (F and G) L. elegans; (H and I) S. australis; (J) S. virgata; (L and M) T. australis. 
For Murayama (1973), cuttings collected during the dormancy period at the end of winter and at the beginning of spring present a greater accumulation of reserves in the branches and tend to root more, since a certain amount of reserve substances needs to be concentrated in cambium tissues in order for rooting to take place.

\section{CONCLUSIONS}

The L. elegans and A. cathartica species present vegetative propagation capacity and satisfactory initial development of the root and shoot systems, regardless of the season of the year, as well as the S. virgata species in the autumn/winter period. C. glabratus and T. australis also have good vegetative propagation capacity, however they vary significantly between the seasons, being more favorable in the late winter/spring. $S$. australis and E. bifida have vegetative propagation capacity, however the rooting is difficult in both evaluated seasons.

\section{ACKNOWLEDGEMENTS}

The authors acknowledge the members of the Laboratório de Engenharia Natural of the Universidade Federal de Santa Maria for their support in this research.

\section{SUBMISSION STATUS}

Received: 18 sep., 2017

Accepted: 26 apr., 2018

\section{CORRESPONDENCE TO}

\section{Paula Wolff Kettenhuber}

Laboratório de Engenharia Natural - LabEN, Universidade Federal de Santa Maria - UFSM, Av. Roraima, 1000, Prédio 44N, CEP 97105-900, Santa Maria, RS, Brasil e-mail: paulakettenhuber@gmail.com

\section{REFERENCES}

Abate I, Grotta M. Ingegneria Naturalistica - Costruire con le Piante - Linee guida all'impiego delle piante negli interventi di ingegneria naturalistica in ambito mediterraneo. Benevento: Edizione Lume; 2009.
Alvares CA, Stape JL, Sentelhas PC, Gonçalves JLM, Sparovek G. Köppen's climate classification map for Brazil. Meteorologische Zeitschrift 2013; 22(6): 711-728. http:// dx.doi.org/10.1127/0941-2948/2013/0507.

Amri E, Lyaruu HVM, Nyomora AS, Kanyeka ZL. Vegetative propagation of African Blackwood (Dalbergia melanoxylon Guill. \& Perr.): effects of age of donor plant, IBA treatment and cutting position on rooting ability of stem cuttings. New Forests 2010; 39(2): 183-194. http:// dx.doi.org/10.1007/s11056-009-9163-6.

Borges N Jr, Martins-Corder MP. Efeito do ácido indolbutírico no enraizamento de estacas de acácia negra (Acacia mearnsii De Wild.). Revista Árvore 2002; 26(2): 223-227.

Bortolini MF, Zuffellato-Ribas KC, Koehler HS, Carpanezzi AA, Deschamps C, Oliveira MDC et al. Tibouchina sellowiana (Cham.) Cogn.: enraizamento, anatomia e análises bioquímicas nas quatro estações do ano. Ciência Florestal 2008; 18(2): 159-171. http://dx.doi. org/10.5902/19805098454.

Coppin NJ, Richards IG. Use of vegetation in civil engineering. 2. ed. London: CIRIA; 2007.

Cornelini P, Ferrari R. Manuale di ingegneria naturalistica per le scuole secondarie. Roma: Regione Lazio; 2008.

Costa RQ, Barbosa GM, Cocozza FM, Reis TC, Nascimento RSM. Desenvolvimento de estacas caulinares de Byrsonima verbascifolia tratadas com ácido indolbutírico. Enciclopédia Biosfera 2013; 9(16): 689-696.

Dias PC, Oliveira LS, Xavier A, Wendling I. Estaquia e miniestaquia de espécies florestais lenhosas do Brasil. Pesquisa Florestal Brasileira 2012; 32(72): 453-462. http:// dx.doi.org/10.4336/2012.pfb.32.72.453.

Durlo MA, Bressan DA, Sutili FJ. Biotécnicas no manejo de cursos de água - Rios da América. Ciência \& Ambiente 2010; 41(1): 69-90

Durlo MA, Sutili FJ. Bioengenharia: manejo biotécnico de cursos de água. 2. ed. Porto Alegre: Editora EST Edições; 2014.

Fachinello JC, Hoffmann A, Nachtigal JC. Propagação de plantas frutíferas. Brasília: Embrapa Informação Tecnológica; 2005.

Fritsch M, Cervi AC. O gênero Escallonia Mutis ex Linnaeus filius (Escalloniaceae) no estado do Paraná, Brasil. Fontqueria 2011; 56(24): 207-226.

Gratieri-Sossella A, Petry C, Nienow AA. Propagação da corticeira do banhado (Erythrina crista-galli L.) (Fabaceae) pelo processo de estaquia. Revista Árvore 2008; 32(1): 163 171. http://dx.doi.org/10.1590/S0100-67622008000100018.

Hartmann HT, Kester DE, Davies FT Jr, Geneve RL. Plant propagation: principles and pratices. 7. ed. New Jersey: Prentice Hall; 2002.

Husen A, Pal M. Variation in shoot anatomy and rooting behaviour of stem cutting in relation to age of donor plants 
in teak (Tectona grandis Linn. F). New Forests 2006; 31(1): 57-73. http://dx.doi.org/10.1007/s11056-004-6794-5.

Lima DM, Biasi LA, Zanette F, Zuffellato-Ribas KC, Bona C, Mayer JLS. Capacidade de enraizamento de estacas de Maytenus muelleri Schwacke com a aplicação de ácido indolbutírico relacionada aos aspectos anatômicos. Revista Brasileira de Plantas Medicinais 2011; 13(4): 422-438. http://dx.doi.org/10.1590/S1516-05722011000400008.

Menegazi G, Palmeri F. II dimensionamento delle opera di ingegneria naturalística. Roma: Regione Lazio; 2013.

Monteiro JS, Leite MB, Wink C, Durlo MA. Influência do ângulo de plantio sobre a brotação e o enraizamento de estacas de Phyllanthus sellowianus (Klotzsch) Müll. Arg. Ciência Florestal 2010; 20(3): 523-532. http://dx.doi. org/10.5902/198050982066.

Moreno JA. Clima do Rio Grande do Sul. Porto Alegre: Secretaria da Agricultura; 1961.

Murayama SJ. Fruticultura. Campinas: Instituto Campineiro de Ensino Agrícola; 1973.

Myers N, Mittermeier RA, Mittermeier CG, Fonseca GAB, Kent J. Biodiversity hotspots for conservation priorities. Nature 2000; 403(6772): 853-845. http://dx.doi. org/10.1038/35002501. PMid:10706275.

Nery FSG, Ribas KCZ, Koehler HS. Enraizamento de Psychotria nuda (Cham. \& Schltdl.) Wawra (Rubiaceae) nas quatro estações do ano. Ciência Florestal 2014; 24(1): 243-250. http://dx.doi.org/10.5902/1980509813341.

Nicoloso FT, Lazzari M, Fortunato RP. Propagação vegetativa de Platanus acerifolia Ait: (II) efeito da aplicação de zinco, boro e ácido indolbutírico no enraizamento de estacas. Ciência Rural 1999; 29(3): 487-492. http://dx.doi. org/10.1590/S0103-84781999000300018.

Nienow AA, Chura G, Petry C, Costa C. Enraizamento de estacas de quaresmeira em duas épocas e concentrações de ácido indolbutírico. Revista Brasileira de Agrociência 2010; 16(1-4): 139-142.

Oliveira MC, Ribeiro JF, Rios MNS, Rezende ME. Enraizamento de estacas para produção de mudas de espécies nativas de Matas de Galeria. Brasília: Embrapa; 2001. (Recomendação Técnica; no. 41).

Oliveira MC, Ribeiro JF. Enraizamento de estacas de Euplassa inaequalis (Pohl) Engl. de Mata de Galeria em diferentes estações do ano. Bioscience Journal 2013; 29(4): 991-999.

Ono EO, Barros SA, Rodrigues JD, Pinho SZ. Enraizamento de estacas de Platanus acerifolia tratadas com auxinas. Pesquisa Agropecuária Brasileira 1994; 29(9): 1373-1380.

Owusu SA, Opuni-Frimpong E, Antwi-Boasiako C. Improving regeneration of mahogany: techniques for vegetative propagation of four African mahogany species using leafy stem cuttings. New Forests 2014; 45(5): 687-697. http://dx.doi.org/10.1007/s11056-014-9431-y.

Pivetta KFL, Pedrinho DR, Fávero S, Batista GS, Mazzini RB. Época de coleta e ácido indolbutírico no enraizamento de estacas de espirradeira (Nerium oleander L.). Revista Árvore 2012; 36(1): 17-23. http://dx.doi.org/10.1590/ S0100-67622012000100003.

Pizzatto M, Wagner A Jr, Luckmann D, Pirola K, Cassol DA, Mazaro SM. Influência do uso de AIB, época de coleta e tamanho de estaca na propagação vegetativa de hibisco por estaquia. Revista Ceres 2011; 58(4): 487-492. http://dx.doi.org/10.1590/S0034-737X2011000400013.

Reitz R, Klein RM, Reis A. Projeto Madeira do Rio Grande do Sul. Rio Grande do Sul: SUDESUL/Governo do Estado do Rio Grande do Sul/Herbário Barbosa Rodrigues; 1988.

Rios MNS, Ribeiro JF. Enraizamento de estacas de cinco espécies de Mata de Galeria em diferentes épocas do ano. Enciclopédia Biosfera 2014; 10(18): 1524-1536.

Sánchez-Soto S, Guedes JC, Nakano O. Neodiplogrammus quadrivittatus (Olivier) (Coleoptera: Curculionidae) no Estado de São Paulo. Neotropical Entomology 2003; 32(3): 511-512. http://dx.doi.org/10.1590/S1519566X2003000300022.

Santander CAB, González IAG. Flora Arbórea del Uruguay - Con énfasis en las especies de Rivera y Tacuarembó. Montevideo: Editora COFUSA; 2007.

Santos JP, Davide AC, Teixeira LAF, Melo AJS, Melo LA. Enraizamento de estacas lenhosas de espécies florestais. Cerne 2011; 17(30): 293-301. http://dx.doi.org/10.1590/ S0104-77602011000300002.

Schiechtl HM. Bioingegneria Forestale: basi - materiali da costruzioni vivi - metodi. Itália: Tipolitografia CastaldiFeltre; 1973.

Silva AGA, Gonçalves CR, Galvão DM, Gonçalves AJL, Gomes J, Silva MN et al. Quarto catálogo dos insetos que vivem nas plantas do Brasil. Seus parasitos e predadores. Rio de Janeiro: Ministério da Agricultura; 1968. Parte 2, Tomo $1^{\circ}$, insetos, hospedeiros e inimigos naturais.

Sousa RS, Sutili FJ. Aspectos técnicos das plantas utilizadas em Engenharia Natural. Revista Ciência \& Ambiente 2017; 46-47: 31-71.

Stuepp CA, Bitencourt J, Wendling I, Koehler HS, Ribas KCZ. Age of stock plants, seasons and IBA effect on vegetative propagation of Ilex paraguariensis. Revista Árvore 2017; 41(2): e410204.

Stuepp CA, Wendling I, Koehler HS, Zuffellato-Ribas KC. Estaquia de árvores adultas de Paulownia fortunei var. mikado a partir de brotações epicórmicas de decepa. Ciência Florestal 2015; 25(3): 667-677. http://dx.doi. org/10.5902/1980509819617. 
Sutili FJ, Dorneles RDS, Vargas CO, Kettenhuber PLW. Avaliação da propagação vegetativa de espécies utilizadas na estabilização de obras de terra com técnicas de Engenharia Natural. Ciência Florestal 2018; 28(1): 1-12. http://dx.doi. org/10.5902/1980509831567.

Tabarelli M, Pinto LP, Silva JMC, Hirota M, Bedê L. Challenges and opportunities for biodiversity conservation in the Brazilian Atlantic Forest. Conservation Biology
2005; 19(3): 695-700. http://dx.doi.org/10.1111/j.15231739.2005.00694.x.

Taiz L, Zeiger E. Fisiologia vegetal. 5. ed. Porto Alegre: Artmed Editora; 2013.

Xavier A, Santos GA. Clonagem em espécies florestais nativas. In: Rocha MGB. Melhoramento de espécies arbóreas nativas. Belo Horizonte: Instituto de Desenvolvimento Florestal Sustentável; 2002. 